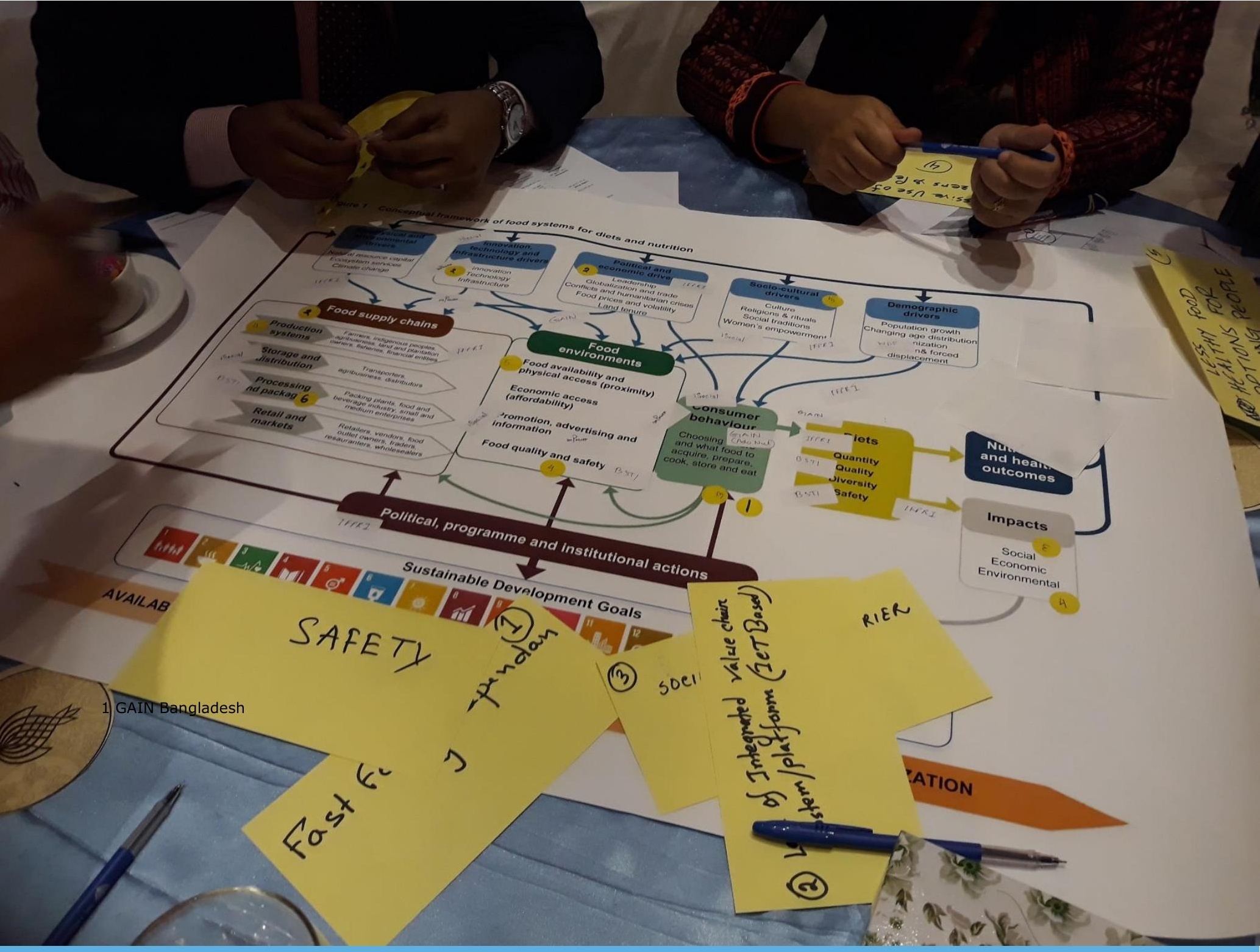

\title{
SUN Business Network Bangladesh workshop on improving Nutrition and Diets through adopting a Food Systems lens
}

Stakeholder engagement and capacity building workshop SUN Business Network Bangladesh

Authors; Ridwam Syed ${ }^{1}$, Tasfia Zaman ${ }^{1}$, Marion Herens², Sanne Bakker ${ }^{2}$, Raffaele Vignola ${ }^{3}$

1 GAIN Bangladesh

2 Wageningen University and Research, Wageningen Centre for Development Innovation

3 Wageningen University and Research, Environmental Policy Group

This research was (partly) funded by IFPRI A4NH, Food Systems for Healthier Diets, under the framework of the Anchoring project coordinated by the Environmental Policy Group of Wageningen University and Research

Wageningen, January 2020

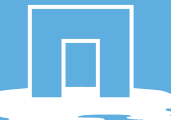

WAGENINGEN

UNIVERSITY \& RESEAREH

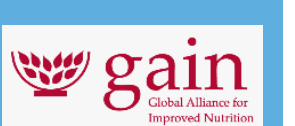


Syed, R., Zaman, T., Herens, M., Bakker, S., Vignola, R. 2020. SUN Business Network Bangladesh Workshop on Improving Nutrition and Diets through adopting a Food Systems lens. Wageningen Centre for Development Innovation, Wageningen University \& Research.

On the 1st of October 2019 GAIN, jointly with WFP and WCDI, organised a one day workshop for the Sun Business Network in Bangladesh to i) to promote deeper and shared understanding of the pathways for improving nutrition and healthier diets through adopting a food systems lens and to contribute to environmental and social responsibility, and ii) to strengthen the capacity of SBN Bangladesh to understand, strategize and steer action to improve nutrition outcomes through adopting a food systems lens. This report summarizes the results of the presentations provided by GAIN, WFP, Light Castle Partners and WCDI, and the outputs of the group work on food system mapping.

Keywords: food systems, nutrition, diets, business, network, Bangladesh.

This report can be downloaded for free at https://doi.org/10.18174/514398 or at www.wur.eu/cdi (under publications).

(C) 2020 Wageningen Centre for Development Innovation, part of the Stichting Wageningen Research. P.O. Box 88, 6700 AB Wageningen, The Netherlands. T + 31 (0)317 4868 00, E info.cdi@wur.nl, www.wur.eu/cdi.

\section{(cc) BY-NC}

The Wageningen Centre for Development Innovation uses a Creative Commons Attribution 4.0 (Netherlands) licence for its reports.

The user may copy, distribute and transmit the work and create derivative works. Third-party material that has been used in the work and to which intellectual property rights apply may not be used without prior permission of the third party concerned. The user must specify the name as stated by the author or licence holder of the work, but not in such a way as to give the impression that the work of the user or the way in which the work has been used are being endorsed. The user may not use this work for commercial purposes.

The Wageningen Centre for Development Innovation accepts no liability for any damage arising from the use of the results of this research or the application of the recommendations.

Photo cover: Marion Herens 



\section{Contents}

$\begin{array}{rlr}1 . & \text { Background } & 4 \\ 2 . & \text { Plenary sessions } & 5 \\ 3 . & \text { Group work } & 6 \\ 4 . \quad \text { Key Findings per group } & 7 \\ 5 . \quad \text { Concluding remarks } & 11 \\ \text { Annex 1 Workshop programme } & \mathbf{1 2} \\ \text { Annex 2 Organisations present in the workshop } & \mathbf{1 3}\end{array}$

Annex 2 Organisations present 


\section{Capacity Building Workshop on "Pathways for Improving Nutrition and Diet through adopting Food Systems lens" for social and environmental sustainability}

\section{Background}

Business in Bangladesh thrives in a complex ecosystem where there are barriers in the overall food systems that impede nutritional outcomes and food safety. In Bangladesh, alarming numbers of people suffer from hunger and the prevalence of child undernutrition and micronutrient deficiency remains very high. Concurrently, the prevalence of overweight and obesity is steadily rising, even among the poorer sections of the population, leading to a rise in non-communicable diseases such as of diabetes, cardiovascular diseases and certain cancers. One of the major underlying issues is the lack of access to affordable, diversified, safe and nutritious diets. Diets in Bangladesh are typically monotonous, dominated by staples, and low in diversity.

The private sector has the capability to influence consumer choices and deliver safe and nutritious food. However, in order to improve diets and nutrition outcomes, it is necessary to better understand the role and position of businesses active the food system. The overall enabling environment for businesses to support healthy diets is influenced by the government, civil society and competing business actors. It is therefore necessary to collaborate with other private sector partners, government, civil society and knowledge partners to open venues for change towards a nutrition sensitive food system.

The Scaling Up Nutrition (SUN) Business Network (SBN), co-convened by Global Alliance for Improved Nutrition (GAIN) and World Food Programme (WFP), is a platform to bring business to together to act and invest in improving nutrition. SBN Bangladesh envisions to bring together the public and private sector in a single national platform to facilitate greater Public Private Partnerships (PPP) and Business to Business (B2B) technical and financial assistance. SBN Bangladesh is crafting a strategy in partnership with Light Castle Partners to meaningfully engage business in nutrition. The Wageningen Centre for Development Innovation (WCDI) and Wageningen University and Research Environmental Policy Group (ENP-WUR) are supporting the SBN to build the capacity on adopting a food systems perspective.

On the 1st of October 2019 GAIN, jointly with WFP, WCDI and ENP-WUR, organised a one day workshop for SBN Bangladesh to i) to promote deeper and shared understanding of the pathways for improving nutrition and healthier diets through adopting a food systems lens and to contribute to environmental and social responsibility, and ii) to strengthen the capacity of SBN Bangladesh to understand, strategize and steer action to improve nutrition outcomes through adopting a food systems lens.

This report summarizes the results of the presentations provided by GAIN, WFP, Light Castle Partners and WCDI, and the results of the interactive sessions. A detailed programme of the workshop can be found in Annex 1. 


\section{Plenary sessions}

The workshop was opened by Mr Ridwan Syed (GAIN Bangladesh) who welcomed all participants and briefed the them on the logic and rationale of the SUN Business Network. He emphasized the need to engage the private sector in the nationwide effort to address the various forms of malnutrition, from the ongoing concerns around undernutrition, micronutrition deficiencies, to the upcoming concerns relating to overnutrition, obesity, changing diets and changing food environments, eventually leading to an increase of non-communicable diseases. He highlighted the progress in convening the SBN and the steps to come.

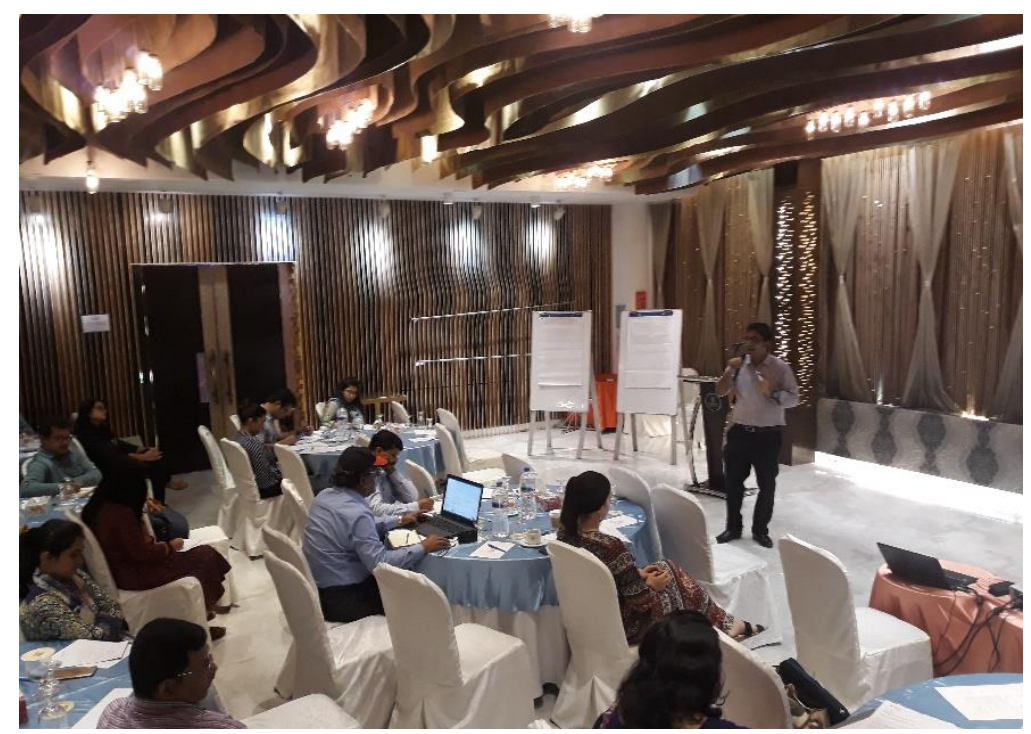

Figure 1 Mr Ridwan Syed presenting SBN updates

After that, participants were welcomed by the project manager of the Ministry of Industries; Dr al Amin Sarker, who emphasized that in its efforts to bring Bangladesh to the status of middle-income country, the Government is fully taking nutrition on board given its effect on socio-economic development. Next, Mrs Coleen O'Connor, WFP Bangladesh, illustrated in more depth the critical developments in the Bangladeshi dietary patterns based on WFP ongoing work on filling the dietary gap.

The third presentation was done by Mr Saif Nazrul, from Light Castle Partners, who presented the preliminary results of a mapping of private sector activities in nutrition, which should inform the development of the SBN Strategy. This mapping included a desk review of existing policy documents and strategies of the SUN Business network, the Government of Bangladesh and donors, as well as business' corporate social responsibility (CSR) strategies. The results will be complemented with findings of key informant interviews and focus group discussions. Mr Saif Nazrul shared the mapping identified the following potential areas of engagement for SBN; food safety, product and dietary diversification, consumer awareness, adolescent and youth nutrition, ethical marketing, geriatric nutrition and workforce nutrition.

Lastly, WCDI introduced the concept of food systems ${ }^{1}$, as a way to put agri-food sector related business activities in their social and environmental context, and think about the different actors involved, their interests, and their behaviour. It was highlighted that food systems, through diets, give rise to a variety of outcomes. These relate not only to nutrition and health, but also to economic, social and

\footnotetext{
${ }^{1}$ Definition of a food system by the High Level Panel of Experts of Food and Nutrition Security (2014); a food system considers all the elements (environment, people, inputs, processes, infrastructures, institutions) and activities that relate to primary producing, processing, distributing, preparing and consuming food; and the social, economic and environmental outcomes of these activities.
} 
environmental outcomes. For those who were new to the concept of food systems, a brief explanatory video was screened. WCDI also presented a list of food system topics in Bangladesh, which were identified as part of a scan of national level policies. The SBN network is established to bring together private sector actors, governments, development partners and CSO's, with the conviction that together you can have more impact than individually. WCDI introduced the principles for effective multistakeholder partnerships and the process model for these types of partnerships.

The slides of the presentations can be obtained by contacting Mr Ridwan Syed

(smridwan@gainhealth.org).

\section{Group work}

Following the plenary sessions, two interactive group work sessions were done throughout the day, a food system mapping and a stakeholder analysis, for which the participants were randomly placed in five subgroups of 5-8 people.

For the mapping exercise, the conceptual framework of food systems for diets and nutrition, developed by the High Level Panel of Experts (HLPE) on Food Security and Nutrition ${ }^{2}$ (see Figure 2), was used.

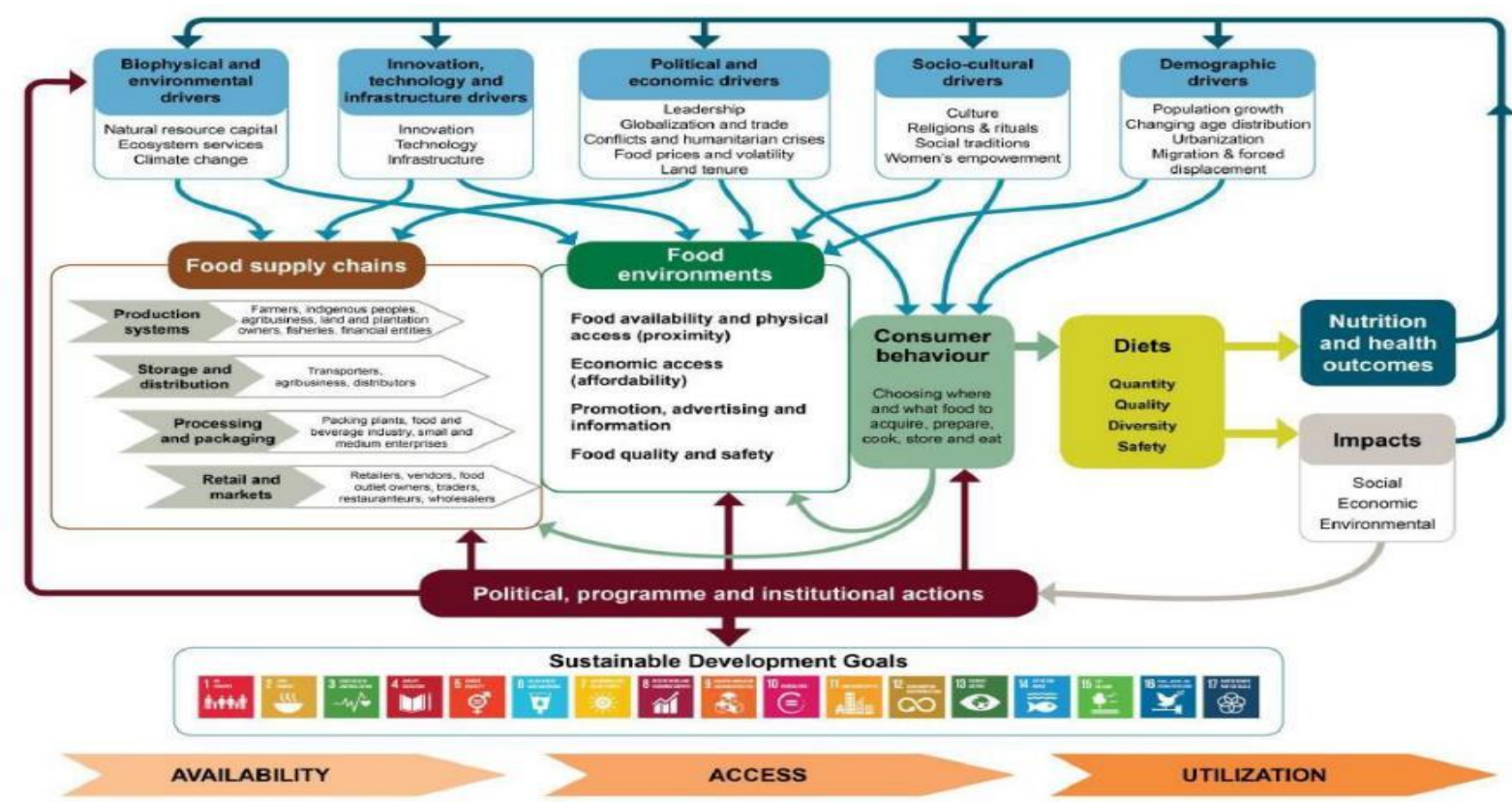

Figure 2 Conceptual framework food systems for diets and nutrition HLPE (2017)

A1 posters of the framework formed the basis for group discussion of how the members view the work and its impact of their respective organizations in the broader food system. All participants mapped their organisation by writing the name of the institution/business on a sticker and placing it on the food system poster to indicate in which food system component(s) each institution is operating. Next, the group members identified the main barriers in food systems impeding access to healthy diets and improved nutrition outcomes. These were also marked on the map and elaborated in a legend. Finally, the groups used post-its to map out on the food systems poster where they could see opportunities to work on improved nutrition outcomes. Box 1 presents the guiding questions for this group work.

\section{Box 1 Guiding questions for food system mapping exercise}

\footnotetext{
${ }^{2}$ HLPE. 2017. Nutrition and food systems. A report by the High Level Panel of Experts on Food Security and Nutrition of the
} Committee on World Food Security, Rome. 
1. Where in the food system are you active?

2. Where do you see barriers to better nutrition?

3. Where do you see opportunities for your institute/business for better nutrition?

4. (after selecting one of the opportunities identified under question 3) With whom would you need to work to get there?

In the afternoon, the groups continued working on one of the opportunities identified during the food system mapping exercise, and listed the major stakeholders needed to translate opportunities into action. A stakeholder matrix was then used to analyse these stakeholders according to level of importance and influence in relation to the opportunity.

\section{Key Findings per group}

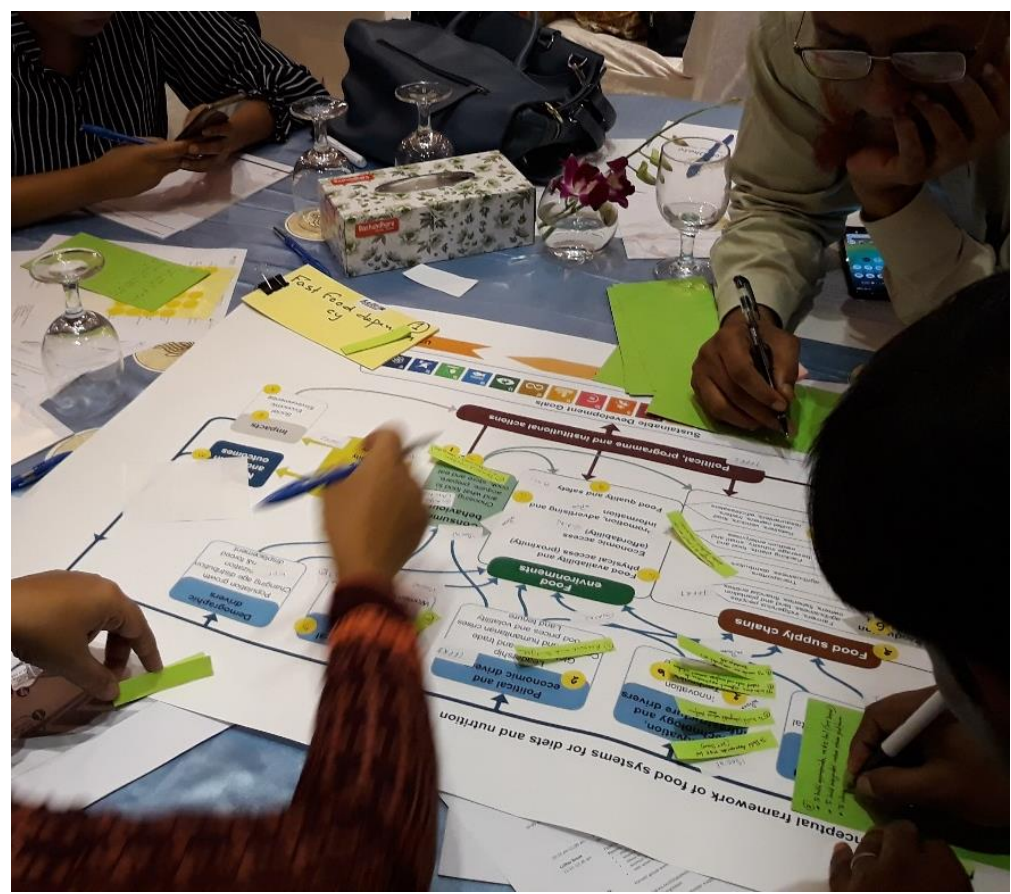

Figure 3 Group work on food system mapping

The group work resulted in food systems posters with stickers indicating barriers and opportunities, and the food system components where the organizations represented at the workshop focus their activities (see Figure 3). Legends to the poster were used to describe the barriers and opportunities with more detail. The outputs have been summarized in table 1 and 2 below. Table 1 presents the food system components and the organizations that indicated to be most active in those components by working group. The outer right column counts the total number of organizations that is active in the food system components across the working groups. The colour in the table highlight common and less common food system components. 
Table 1 SBN members and respective food system components

\begin{tabular}{|c|c|c|c|c|c|c|}
\hline $\begin{array}{l}\text { Food system } \\
\text { component }\end{array}$ & Group 1 & Group 2 & Group 3 & Group 4 & Group 5 & $\begin{array}{l}\text { Total \# } \\
\text { organiza } \\
\text { tions* }\end{array}$ \\
\hline $\begin{array}{l}\text { Biophysical and } \\
\text { environmental drivers }\end{array}$ & $\begin{array}{l}\text { CARE BD } \\
\text { WaterAid }\end{array}$ & ACI Agribusiness & mPower & & IFPRI & 5 \\
\hline Socio-cultural drivers & $\begin{array}{l}\text { CARE BD } \\
\text { GAIN WNP }\end{array}$ & & BRAC & PLAN & iSocial & 5 \\
\hline Demographic drivers & & & BRAC & & & 1 \\
\hline $\begin{array}{l}\text { Political and economic } \\
\text { drivers }\end{array}$ & GAIN-WNP & & BFSA & PARMEEDA & IFPRI & 4 \\
\hline $\begin{array}{l}\text { Political, programme and } \\
\text { institutional action }\end{array}$ & $\begin{array}{l}\text { CARE BD } \\
\text { WaterAid }\end{array}$ & & & & & 2 \\
\hline $\begin{array}{l}\text { Food availability and } \\
\text { physical access }\end{array}$ & & & iSocial & & & 1 \\
\hline Production systems & & $\begin{array}{l}\text { BASF } \\
\text { Voice of South } \\
\text { Bangladesh } \\
\text { FAO }\end{array}$ & mPower & $\begin{array}{l}\text { PARMEEDA } \\
\text { Prakriti farming } \\
\text { DLS }\end{array}$ & IFPRI & 8 \\
\hline Food supply chains & & & BRAC & Prakriti Farming & & 2 \\
\hline Storage and distribution & $\begin{array}{l}\text { WaterAid } \\
\text { BAPA } \\
\text { CWW }\end{array}$ & $\begin{array}{l}\text { ACI Agribusiness } \\
\text { BASF } \\
\text { SNV }\end{array}$ & $\begin{array}{l}\text { IGLOO } \\
\text { IFPRI }\end{array}$ & & $\begin{array}{l}\text { iSocial } \\
\text { BSTI }\end{array}$ & 10 \\
\hline Processing and packaging & GAIN-WNP & $\begin{array}{l}\text { BASF } \\
\text { Banoful Kiswan }\end{array}$ & iSocial & & iSocial & 4 \\
\hline Retail and markets & $\begin{array}{l}\text { CARE BD } \\
\text { GAIN-WNP }\end{array}$ & Banoful Kiswan & & & & 3 \\
\hline $\begin{array}{l}\text { Innovation, technology } \\
\text { and infrastructure }\end{array}$ & $\begin{array}{l}\text { GAIN-WNP } \\
\text { WaterAid } \\
\text { CWW }\end{array}$ & $\begin{array}{l}\text { ACI Agribusiness } \\
\text { BASF } \\
\text { Banoful Kiswan } \\
\text { SNV }\end{array}$ & $\begin{array}{l}\text { MPower } \\
\text { iSocial }\end{array}$ & & $\begin{array}{l}\text { mPower } \\
\text { GAIN } \\
\text { Adolescent } \\
\text { Nutrition Team }\end{array}$ & 9 \\
\hline Food quality and safety & $\begin{array}{l}\text { GAIN-WNP } \\
\text { BAPA } \\
\text { CWW }\end{array}$ & $\begin{array}{l}\text { ACI Agribusiness } \\
\text { Banoful Kiswan }\end{array}$ & $\begin{array}{l}\text { IFPRI } \\
\text { BFSA }\end{array}$ & DLS & $\begin{array}{l}\text { IFPRI } \\
\text { BSTI }\end{array}$ & 9 \\
\hline $\begin{array}{l}\text { Promotion, advertising } \\
\text { and information }\end{array}$ & & $\begin{array}{l}\text { Voice of South } \\
\text { Bangladesh } \\
\text { FAO }\end{array}$ & $\begin{array}{l}\text { IGLOO } \\
\text { BRAC }\end{array}$ & & $\begin{array}{l}\text { iSocial } \\
\text { mPower }\end{array}$ & 6 \\
\hline Food environments & $\begin{array}{l}\text { CARE BD } \\
\text { WaterAid }\end{array}$ & & & & & 2 \\
\hline $\begin{array}{l}\text { Affordability for } \\
\text { consumers }\end{array}$ & & SNV & & & & 1 \\
\hline Consumer behaviour & $\begin{array}{l}\text { CARE BD } \\
\text { GAIN-WNP }\end{array}$ & $\begin{array}{l}\text { SNV } \\
\text { Voice of South } \\
\text { Bangladesh } \\
\text { FAO }\end{array}$ & $\begin{array}{l}\text { BRAC } \\
\text { iSocial }\end{array}$ & $\begin{array}{l}\text { PARMEEDA } \\
\text { PLAN } \\
\text { HOPLUN Ltd }\end{array}$ & $\begin{array}{l}\text { iSocial } \\
\text { mPower } \\
\text { GAIN } \\
\text { Adolescent } \\
\text { Nutrition Team }\end{array}$ & 11 \\
\hline $\begin{array}{l}\text { Diets, nutrition and health } \\
\text { outcomes }\end{array}$ & $\begin{array}{l}\text { CARE BD } \\
\text { GAIN_WNP } \\
\text { WaterAid }\end{array}$ & $\begin{array}{l}\text { Voice of South } \\
\text { Bangladesh } \\
\text { FAO }\end{array}$ & $\begin{array}{l}\text { IFPRI } \\
\text { iSocial }\end{array}$ & $\begin{array}{l}\text { PARMEEDA } \\
\text { HOPLUN Ltd }\end{array}$ & $\begin{array}{l}\text { mPower } \\
\text { GAIN Adolscent } \\
\text { Nutrition Team }\end{array}$ & 10 \\
\hline SDGs & WaterAid & & & & & 1 \\
\hline $\begin{array}{l}\text { Migration and forced } \\
\text { displacement }\end{array}$ & CWW & & & & WDP & 2 \\
\hline
\end{tabular}

* To count the total number of organizations working on a food system component, GAIN-WNP and GAIN adolescent nutrition team were considered the same organization.

$<5$ organizations

5-9 organization

$\geq 10$ organizations

Table 2 summarizes the barriers and opportunities by group. 


\begin{tabular}{|c|c|c|c|c|}
\hline Group & \multicolumn{2}{|c|}{ Barriers } & \multicolumn{2}{|r|}{ Opportunities for the business/institutions } \\
\hline $\begin{array}{l}\text { Group } 1 \text { - } \\
\text { CARE, GAIN } \\
\text { (Workforce } \\
\text { Nutrition } \\
\text { Team), } \\
\text { WaterAid , } \\
\text { CWW, BAPA) }\end{array}$ & b) & $\begin{array}{l}\text { According to the group, the transportation } \\
\text { system in rural areas is underdeveloped, } \\
\text { which as a result slows down the whole } \\
\text { transportation process of fresh } \\
\text { produced/harvested crops or fruits from the } \\
\text { field to the retail market. Therefore, there } \\
\text { is a need for modern transportation and } \\
\text { infrastructure in rural areas. } \\
\text { The group believes that the demand for } \\
\text { nutritious food is limited which gives the } \\
\text { manufacturers to market unhealthy or } \\
\text { unsafe food to the mass population. } \\
\text { Furthermore, people are still unaware of } \\
\text { the actual definition of nutrition; they lack } \\
\text { education when it comes to defining } \\
\text { micronutrients, protein etc, and the right } \\
\text { amount of such elements our body } \\
\text { requires. As a result, lesser people resort to } \\
\text { healthy, nutritious food. } \\
\text { The sectors in question require a lot of } \\
\text { women to be deployed but majority of } \\
\text { these women are unskilled or uneducated } \\
\text { or unwilling to explore to their full potential } \\
\text { due to societal boundaries. Therefore, it is } \\
\text { harder to on board women in all stages of } \\
\text { the food system. Also, according to this } \\
\text { group, the prices of goods or commodities } \\
\text { tend to fluctuate a lot, making it harder for } \\
\text { them to supply things exactly according to } \\
\text { the demand for it. There is also, high } \\
\text { involvement of government in these sectors } \\
\text { which makes the whole food systems } \\
\text { process bureaucratic. Furthermore, as } \\
\text { political intervention is necessary, the } \\
\text { policy makers still fail to deploy a } \\
\text { harmonized food safety standard. } \\
\text { Due to increased level of migration in the } \\
\text { country, more urban slums are set up thus } \\
\text { making more places look underdeveloped. }\end{array}$ & b) & $\begin{array}{l}\text { There is a scope for the provision of developed } \\
\text { and innovative infrastructure and technology in } \\
\text { this sector. } \\
\text { In order to promote safe and nutritious food in } \\
\text { these sectors and to train more people, seminars } \\
\text { may be hosted to highlight the need of } \\
\text { consuming the right micronutrients, ways of } \\
\text { keeping and safely preparing and preserving } \\
\text { food, and so on. } \\
\text { Field level farmers use natural fertilizers instead } \\
\text { of artificial ones, leading to a safe and healthy } \\
\text { production of crops and vegetables. }\end{array}$ \\
\hline $\begin{array}{l}\text { Group } 2 \text { (ACI } \\
\text { Agribusiness, } \\
\text { BASF, } \\
\text { Banoful } \\
\text { Kiswan, } \\
\text { Elson Foods, } \\
\text { SNV, Voice of } \\
\text { Bangladesh, } \\
\text { FAO) }\end{array}$ & a) & $\begin{array}{l}\text { Food manufacturers/processors fail to } \\
\text { promote the nutritional content through } \\
\text { packaging or labels, leaving the consumers } \\
\text { uninformed about what healthy or } \\
\text { unhealthy food/drink they are consuming. } \\
\text { Advertisement is not effective in } \\
\text { Bangladesh thereby leading to inadequate } \\
\text { education on the types, benefits and } \\
\text { outcomes of consuming nutritious food. } \\
\text { Growing production of counterfeit products } \\
\text { leads to improper diet. There is a lack of } \\
\text { regular monitoring of food production and } \\
\text { there is no right implementation of laws } \\
\text { regarding food quality and safety. } \\
\text { Farmer's affordability of inputs such as } \\
\text { fertilizers, pesticides and seeds depend on } \\
\text { the price of the crops. Therefore, if the } \\
\text { price is less then quality of crops is } \\
\text { degraded, thus forming a vicious cycle. } \\
\text { As people are resistant towards spending } \\
\text { more on nutritious food, retail and } \\
\text { wholesale outlets need to deploy costly } \\
\text { promotional tools and invest more on } \\
\text { research and development. } \\
\text { Lack of technical knowledge and poverty of } \\
\text { rural communities reduce consumption of } \\
\text { nutritious food. Therefore, access to finance } \\
\text { is also less. }\end{array}$ & $\begin{array}{l}\text { c) } \\
\text { d) } \\
\text { e) }\end{array}$ & $\begin{array}{l}\text { Food manufacturers may sell nutritious food to } \\
\text { customers, and proper food quality can be } \\
\text { represented on food labels, as well as consumer } \\
\text { awareness. } \\
\text { Farmers can be encouraged to use quality inputs } \\
\text { for food production by ensuring a minimum, } \\
\text { appropriate and fair crop cost. } \\
\text { Environmental policies and rules can be } \\
\text { promoted to meet a vast consumer base through } \\
\text { electronic and print media. } \\
\text { There should be a scope to work with relevant } \\
\text { stakeholders such as MOI, BSTI, various factories } \\
\text { etc for capacity building. } \\
\text { There is a dialogue, collaboration, engagement, } \\
\text { policy-advocacy enabling environment. }\end{array}$ \\
\hline
\end{tabular}




\begin{tabular}{|c|c|c|c|c|}
\hline $\begin{array}{l}\text { Group } 3 \\
\text { (IGLOO, } \\
\text { BRAC, } \\
\text { mPower, } \\
\text { iSocial, } \\
\text { IFPRI, BFSA) }\end{array}$ & $\begin{array}{l}\text { d) } \\
\text { e) } \\
\text { f) }\end{array}$ & $\begin{array}{l}\text { According to this group, the customer base } \\
\text { is still unaware about the concept of food } \\
\text { systems and nutrition, which in turn gives } \\
\text { the market actors the chance to not abide } \\
\text { with proper standards when } \\
\text { manufacturing, processing or packaging } \\
\text { food. } \\
\text { There seems to be wrong understanding of } \\
\text { nutrition or food habits which is why the } \\
\text { mass market opts for unhealthy food. } \\
\text { Apparently, there is a presence of } \\
\text { appropriate market linkage to ensure fair } \\
\text { pricing at producer level. } \\
\text { Lack of policy advocacy on fortification to } \\
\text { address micronutrient deficiencies. } \\
\text { Value/supply chain does not reliably reach } \\
\text { the bottom of the pyramid. } \\
\text { The primary production process seems to } \\
\text { lack a lot of important resources or } \\
\text { incentives to produce safe, nutritious food. }\end{array}$ & $\begin{array}{l}\text { a) } \\
\text { b) } \\
\text { c) }\end{array}$ & $\begin{array}{l}\text { PPP to use existing government and health } \\
\text { services management tools and promote the } \\
\text { benefits of consuming nutritious food. } \\
\text { The sectors in question have access to dedicated } \\
\text { last-mile solution that aggregates storage, } \\
\text { delivery and sales needs of multi-stakeholders. } \\
\text { Integrated last-mile dedicated solution with } \\
\text { capability for business, data collection and } \\
\text { development exist within the reach of these } \\
\text { sectors. } \\
\text { The supply chain is linked directly to the food } \\
\text { system. } \\
\text { Culture, value and knowledge have an impact on } \\
\text { the food environment and consumer behaviour } \\
\text { as food safety and quality awareness and } \\
\text { education can have a positive impact on actual } \\
\text { nutritious food consumption. } \\
\text { Growth in population, rapid urbanization, } \\
\text { migration, rising age distribution leads to } \\
\text { increased food production, thereby increasing the } \\
\text { chances of nutritious food consumption. }\end{array}$ \\
\hline $\begin{array}{l}\text { Group } 4 \\
\text { (PARMEEDA, } \\
\text { Prakriti } \\
\text { Farming, } \\
\text { PLAN, DLS, } \\
\text { Hoplun Ltd.) }\end{array}$ & a) & $\begin{array}{l}\text { Consumer behaviour is the biggest barrier } \\
\text { to food systems, as people opt for delicious } \\
\text { or artificially flavoured food rather than } \\
\text { healthy, nutritious food. } \\
\text { Customer behaviour is also influenced as } \\
\text { there is a disparity in food safety and } \\
\text { quality policy making and control. There is } \\
\text { also a lack of diversified food that makes } \\
\text { consuming nutritious food appear } \\
\text { monotonous to people. } \\
\text { Consumers do not know the right levels of } \\
\text { essential nutrients to be consumed. Food } \\
\text { adulteration often tends to occur on the } \\
\text { market, increasing unhealthy food } \\
\text { consumption. }\end{array}$ & c) & $\begin{array}{l}\text { The use and processing of dairy products into } \\
\text { products such as yogurt, cheese and ice cream } \\
\text { helps to ensure diversity and nutritional status } \\
\text { for all classes of people. } \\
\text { There will be an increase in the consumption of } \\
\text { nutritious food by providing funding and support } \\
\text { to small and medium-sized organizations that } \\
\text { grow and sell safe quality food. Farmers should } \\
\text { also be equipped to create sustainable products } \\
\text { in order to increase access to and affordability of } \\
\text { nutritious food. } \\
\text { Climate smart cultivation is a method of making } \\
\text { a safer course for adolescent dietary habits. } \\
\text { Through enhancing the genetic quality of breeds, } \\
\text { livestock can sustainably produce more amounts } \\
\text { of milk, meat and eggs. Furthermore, the } \\
\text { implementation of CSR activities through } \\
\text { technologically advanced and eco-friendly } \\
\text { production will allow best quality of food to be } \\
\text { produced, packaged and processed. } \\
\text { Faster transaction management allows good } \\
\text { connectivity among consumers and producers } \\
\text { and saves so much time for distribution. } \\
\text { The eco-system, natural resources and climate in } \\
\text { Bangladesh is the most optimal way of creating a } \\
\text { balanced and nutritious food system. }\end{array}$ \\
\hline $\begin{array}{l}\text { Group } 5 \\
\text { (IFPRI, } \\
\text { iSocial, BSTI, } \\
\text { mPower, } \\
\text { GAIN, WDP) }\end{array}$ & a) & $\begin{array}{l}\text { Lack of awareness of nutrient identification } \\
\text { contributes to the intake of common } \\
\text { nutrients such as carbohydrates, trans fat, } \\
\text { etc. This gives people less quantities of } \\
\text { diversified healthy food and the young } \\
\text { generation end up resorting to fast food. } \\
\text { The lack of an integrated value chain } \\
\text { system allows food systems to work more } \\
\text { slowly, thereby hampering their quality and } \\
\text { safety. } \\
\text { Improper use of synthetic fertilizers and } \\
\text { pesticides significantly reduces the benefits } \\
\text { of nutritious food intake. }\end{array}$ & a) & $\begin{array}{l}\text { Creating a tracking tool for managing food supply } \\
\text { chains / systems can reduce errors, allowing for } \\
\text { a more cohesive operation. } \\
\text { Building an integrated value chain platform, } \\
\text { appropriate M\&E ICT tools, an integrated ICT hub } \\
\text { will enable organizations to produce food more } \\
\text { quickly and enable quality to be maintained and } \\
\text { more diversity to be considered. This will also } \\
\text { allow better collection and analysis of data in } \\
\text { order to judge the situation of food systems. } \\
\text { More female entrepreneurs should be hired to } \\
\text { promote nutritious food to affect consumer } \\
\text { behaviour. The introduction of ICT tools for youth } \\
\text { and women will increase awareness among all } \\
\text { age groups. It is also possible to use e-learning } \\
\text { technologies to facilitate the advantages of } \\
\text { eating healthy and nutritious food. }\end{array}$ \\
\hline
\end{tabular}




\section{Concluding remarks}

This workshop was the second convening of the SBN after the formation of SBN in July 2019. The interest in the network is growing. The network aims to further increase the variety of members, and especially the representation of the private sector.

The private sector can play a big role production in improving nutrition through the promotion and delivery of safe and nutritious foods. This workshop introduced the SBN members to the concept of using a food system lens for improving nutrition. This concept has been used in the development sector for a few years now, but is relatively new for the private sector. The workshop objective to raise awareness has been achieved and participants have been encouraged to reflect on their own role in the food system, as well as the range of environments, people, inputs, processes, infrastructures, institutions and activities in the same food system. As a follow up, it could be helpful to clearly define how using a food systems lens is relevant for business objectives, in other words, "What's in it for them"?

The outputs of the workshop showed that most participants considered their organizations to be active in the area of storage and distribution, consumer behaviour, and diet, nutrition and health outcomes ( $\geq 10$ organizations), followed by Innovation, technology and infrastructure and Food quality and safety ( 9 organizations). Most of the barriers reported by the groups related to low consumer awareness on healthy diets, and, as a result, low demand for nutritious foods. Other barriers related to food production were lack of access to inputs and the use of synthetic fertilizers and pesticides.

Remarkably, environmental sustainability, as a driver and impact area of the food system, was not mentioned often in the discussions and outputs. Ample evidence shows that environmental pollution in Bangladesh is resulting in unsafe food consumption ${ }^{3}$. The main focus of the SBN lies on nutrition outcomes through food systems transitions that lead to healthier diets. However, nutrition outcomes can only be sustained if the food systems delivers healthy diets for all in such a way that the economic, social and environmental bases to generate food security and nutrition for future generations are not compromised. Some of the solutions identified during the workshop, such as production and processing of dairy products, require conscious efforts to limit environmental impact.

The workshop also offered a first occasion for SBN members to think of opportunities for better nutrition (for which partnership could possibly be facilitated through the SBN). The opportunities involved several channels to educate consumers, such as through food labels, government health services, and seminars. The groups also saw opportunities in supporting farmers that produce nutritious foods, e.g. with quality inputs in innovations to facilitate food value chains.

The next step will be to convene SBN meetings at regional level, and take the opportunity to anchor the food systems perspective into the work of the regional level networks. The interactive group session might be used to understand see how regional stakeholders reflect on their role and influence on improving nutrition through a food system lens.

\footnotetext{
${ }^{3}$ https://www.reuters.com/article/us-bangladesh-rivers/bangladesh-river-pollution-threatens-millionsidUSTRE54I04G20090519
} 


\section{Appendix 1 Workshop programme}

\begin{tabular}{|c|c|c|}
\hline Time & Session title & Responsibility \\
\hline 9:00 am & Registration & GAIN \\
\hline $\begin{array}{l}9: 30 \text { am-9:45 } \\
\text { am }\end{array}$ & Welcome & $\begin{array}{l}\text { Scaling Up Nutrition (SUN) } \\
\text { Business Network (SBN) } \\
\text { Coordinator }\end{array}$ \\
\hline $\begin{array}{l}\text { 9:45 am-10:05 } \\
\text { am }\end{array}$ & $\begin{array}{l}\text { Agenda setting, objective and rational } \\
\text { of the workshop, incl. } \\
\text { - Intro GAIN, WFP } \\
\text { - SUN structure } \\
\text { - SBN (global) } \\
\text { - Def ' better nutrition' }\end{array}$ & $\begin{array}{l}\text { SBN Coordinator and World } \\
\text { Food Programme (WFP) }\end{array}$ \\
\hline $\begin{array}{l}10: 05 \text { am-10.25 } \\
a m\end{array}$ & $\begin{array}{l}\text { Introduction on the workshop in the } \\
\text { context of Anchoring. Food System } \\
\text { for Healthier Diet (FSHD) perspective } \\
\text { and progress in Bangladesh, } \\
\text { Anchoring description, MSPs work and } \\
\text { why SBN } \\
\text { - Refer to narrative 'better nutrition' link ' } \\
\text { healthier diets' } \\
\text { Also show Dutch diamond: why do we } \\
\text { work with slogan " From aid to trade' - } \\
\text { check WCDI presentation } \\
\text { - Integrate work done under the platform } \\
\text { for healthier diets project }\end{array}$ & $\begin{array}{l}\text { Wageningen Centre for } \\
\text { Development Innovation } \\
\text { (WCDI) and Environmental } \\
\text { Policy Group (ENP) }\end{array}$ \\
\hline $\begin{array}{l}10: 25 \text { am-11:00 } \\
\text { am }\end{array}$ & $\begin{array}{l}\text { Private Sector Mapping and SBN } \\
\text { Strategy development process and } \\
\text { progress }\end{array}$ & Light Castle Partners (LCP) \\
\hline \multicolumn{3}{|l|}{ Coffee Break } \\
\hline $\begin{array}{l}11: 15-12: 45 \\
\text { am }\end{array}$ & $\begin{array}{l}\text { Food System Assessment by Private } \\
\text { Sector + Plenary. Use FSHD } \\
\text { framework to discuss: } \\
\text { - Where are you working in the food } \\
\text { systems } \\
\text { - Where do you see major } \\
\text { concerns/barriers } \\
\text { - Where do you see your opportunities for } \\
\text { business/ change } \\
\text { - With whom would you need to work to } \\
\text { get there? }\end{array}$ & $\begin{array}{l}\text { WCDI/all - interactive } \\
\text { session in subgroups } \\
\text { Facilitation WCDI }\end{array}$ \\
\hline \multicolumn{3}{|l|}{ Lunch Break } \\
\hline $1: 40-2: 40 \mathrm{pm}$ & Harvest group work & Facilitation WCDI \\
\hline \multicolumn{3}{|l|}{ Coffee break } \\
\hline $3: 00$ to $3: 20 \mathrm{pm}$ & $\begin{array}{l}\text { Introduce Multistakeholder principles } \\
\text { and link to SBN Bangladesh }\end{array}$ & WCDI \\
\hline $3: 20$ to $4: 30 \mathrm{pm}$ & $\begin{array}{l}\text { Group work; stakeholder mapping + } \\
\text { quick power analysis. }\end{array}$ & $\begin{array}{l}\text { Facilitation WCDI } \\
\text { Same subgroups which } \\
\text { worked on the posters }\end{array}$ \\
\hline $4: 30$ to $5: 00 \mathrm{pm}$ & SBN Action Planning & $\begin{array}{l}\text { WCDI/GAIN/WFP } \\
\text { Ridwan: to share work plan }\end{array}$ \\
\hline $5: 15$ to $5: 30 \mathrm{pm}$ & Summary of the Day & WCDI/GAIN/WFP \\
\hline
\end{tabular}





\section{Appendix 2 Organisations present in the workshop}

\begin{tabular}{|c|c|c|}
\hline Sector & Organization & Count \\
\hline \multirow[t]{7}{*}{$\begin{array}{l}\text { International } \\
\text { NGO }\end{array}$} & $\begin{array}{l}\text { CARE BD: One of the world's largest international humanitarian organizations, committed to helping families in poor communities in } \\
\text { improving their lives and alleviating poverty. }\end{array}$ & 1 \\
\hline & $\begin{array}{l}\text { GAIN: } \\
\text { - The Workforce Nutrition Programme aims to improve nutrition of workers in the RMG and textile industry of Bangladesh. } \\
\text { - The Adolescent Nutrition Programme delivers nutritious, safe, affordable, and sustainable diets and takes care of the nutrition } \\
\text { needs of present and future generation children and adolescents. } \\
\text { - Scaling Up Nutrition (SUN) Business Network (SBN) co-convened by Global Alliance for Improved Nutrition (GAIN) and World } \\
\text { Food Programme (WFP) is a platform to bring business to together to act and invest in nutrition. }\end{array}$ & 4 \\
\hline & $\begin{array}{l}\text { Voice of South Bangladesh: It aims to work with the poor and disadvantaged people including the indigenous community, to improve } \\
\text { their standard of living through Information and Communication Technology (ICT) and multifaceted development interventions. }\end{array}$ & 1 \\
\hline & $\begin{array}{l}\text { PLAN: Targets the most excluded children and its programmes directly benefit over } 2.3 \text { million children across Bangladesh. It implements } \\
\text { the following: } \\
\text { - Improves access to quality health services. } \\
\text { - Strengthens the education system. } \\
\text { - Improates safe communities for children. } \\
\text { - Prevents the disasters of natural disasters and climate change. } \\
\text { - Increases the social participation of young people in the society. }\end{array}$ & 1 \\
\hline & Wateraid: Through this platform, more $\mathbf{t 3 . 7}$ million gain access to safe water, and 9.7 million people gain access to proper sanitation. & 1 \\
\hline & $\begin{array}{l}\text { SNV: This started in Bangladesh to design impact-oriented and future scalable programmes to help turn poverty into prosperity. They are } \\
\text { experts in agriculture, energy and water, sanitation and hygiene (WASH). }\end{array}$ & 1 \\
\hline & $\begin{array}{l}\text { FAO: FAO's assistance in Bangladesh matches FAO's expertise to the country's development priorities and is centred on four priority } \\
\text { areas: } \\
\text { - Reduce poverty and enhance food security and nutrition. } \\
\text { - Enhance agricultural productivity through diversification/intensification, sustainable management of natural resources, use of } \\
\text { - Iuality inputs and mechanization. }\end{array}$ & 1 \\
\hline
\end{tabular}




\begin{tabular}{|c|c|c|}
\hline & - $\quad$ Further improve technology generation and adaptation through better producer extension-research linkages. & \\
\hline \multirow[t]{3}{*}{ NGO } & $\begin{array}{l}\text { WDP: Implements the following activities: } \\
\text { - Organization Building of Poor \& Development. } \\
\text { - Human Resources \& Skill Development Training. } \\
\text { - Women Employment \& Income Generation. } \\
\text { - Micro-credit and Savings Accumulation. }\end{array}$ & 1 \\
\hline & $\begin{array}{l}\text { BRAC: An international development organization and global leader in developing cost-effective, evidence-based programmes in conflict } \\
\text { prone and post disaster settings. It has facilities in the following areas: } \\
\text { - Microfinance } \\
\text { - Education } \\
\text { - Healthcare } \\
\text { - Legal rights } \\
\text { - Women empowerment } \\
\text { - Banking }\end{array}$ & 1 \\
\hline & $\begin{array}{l}\text { CWW: Children Without Worms aims to enhance the health and development of children by reducing intestinal worm infections. It } \\
\text { provides technical assistance and resources to soil transmitted helminthiasis (STH) control programmes and guides and it moves with the } \\
\text { goal of eliminating STH as a public health problem. }\end{array}$ & 1 \\
\hline $\begin{array}{l}\text { Industry } \\
\text { Association }\end{array}$ & $\begin{array}{l}\text { BAPA: Bangladesh Agro Processing Association has an overwhelming impact on macroeconomic objectives of Bangladesh including } \\
\text { employment generation, poverty alleviation, human resources development and food security. }\end{array}$ & 1 \\
\hline \multirow[t]{4}{*}{ Private Sector } & $\begin{array}{l}\text { ACI Agribusiness: The largest integrator in agriculture and livestock and fisheries. It has a large, knowledgeable and high-skilled field } \\
\text { force which provides training and technical support to farmers. }\end{array}$ & 1 \\
\hline & $\begin{array}{l}\text { BASF: It offers a wide range of products and solutions to support industries in Bangladesh, ranging from chemicals, plastics and } \\
\text { performance products to agricultural products and care chemicals. It contributes to the local community through selected projects } \\
\text { focusing on health and hygiene. }\end{array}$ & 1 \\
\hline & $\begin{array}{l}\text { Banoful Kiswan: A well-known diversified food processing company in Bangladesh that has prime objective to promote public welfare } \\
\text { through supply of pure and nutritious food in absolute hygienic way. }\end{array}$ & 1 \\
\hline & $\begin{array}{l}\text { PARMEEDA: It is an agribusiness organization devoted and committed to provide safe and organic food to consumers of all over } \\
\text { Bangladesh. It also enforces ecological farming in a sustainable business manner. }\end{array}$ & 1 \\
\hline
\end{tabular}




\begin{tabular}{|c|c|c|}
\hline & $\begin{array}{l}\text { Hoplun Ltd: It is a leading international fashion lingerie and swimwear company. We provide excellent services that aim to deliver the } \\
\text { best price and quality. With the help of GAIN the workforce nutrition of around } 4500 \text { employees are ensured. }\end{array}$ & 1 \\
\hline & $\begin{array}{l}\text { iSocial: A social enterprise working to benefit women, children and adolescents. It drives to unify opportunities by women as a change } \\
\text { agent. }\end{array}$ & 2 \\
\hline & $\begin{array}{l}\text { mPower: A social enterprise that is driving the development sector to an information age. When it comes to nutrition and health, it has } \\
\text { programmes like: } \\
\text { a) Maternal and child health } \\
\text { b) Vaccination tracking } \\
\text { c) Electronic media records } \\
\text { d) Remote doctor consultation }\end{array}$ & 2 \\
\hline & $\begin{array}{l}\text { Elson Foods: One of the premier brands of quality confectionary in Bangladesh with the core business which focuses on candy } \\
\text { manufacturing, with an aim to produce finer products at an affordable price. }\end{array}$ & 1 \\
\hline & $\begin{array}{l}\text { IGLOO: Igloo is the most popular impulse and take-home ice cream of Bangladesh. Equipped with the most modern machinery, skilled } \\
\text { human resources and using only the best ingredients, IGLOO never compromises on quality and taste. }\end{array}$ & 1 \\
\hline & $\begin{array}{l}\text { Prakriti Farming: Involves producing organic food with sustainable urban and rural farming. They produce and train farmers for food } \\
\text { production, create market linkage. They believe in growing their food by protecting the soil, air and nature. }\end{array}$ & 1 \\
\hline \multirow[t]{3}{*}{ Public Sector } & $\begin{array}{l}\text { BSTI - Bangladesh Standards and Testing Institution: It includes primary activities such as: } \\
\text { a) Standardization of services and products } \\
\text { b) Introduction of unit system of weights and measures and promotion of metrology services } \\
\text { c) Promotion and quality assurance activities } \\
\text { d) Rendering testing facilities for services and products } \\
\text { e) Preparation, promotion and adoption of national standards. }\end{array}$ & 1 \\
\hline & $\begin{array}{l}\text { DLS - Department of Livestock Services: It is a Bangladesh government department under the Ministry of Fisheries and Livestock } \\
\text { responsible for Livestock industry in Bangladesh. }\end{array}$ & 1 \\
\hline & $\begin{array}{l}\text { BASF- Bangladesh Food Safety Authority: It offers a wide range of products and services to support industries in Bangladesh, ranging } \\
\text { from chemicals, plastics and performance products to agricultural products and care chemicals. It contributes to the local community } \\
\text { through selected projects focusing on health and hygiene. }\end{array}$ & 1 \\
\hline $\begin{array}{l}\text { International } \\
\text { Organization }\end{array}$ & $\begin{array}{l}\text { IFPRI- International Food Policy Research Institute: Provides research-based policy solutions to sustainably reduce power and hunger } \\
\text { and malnutrition in developing countries. }\end{array}$ & 2 \\
\hline \multicolumn{2}{|c|}{ Total Participants } & 31 \\
\hline
\end{tabular}


Wageningen Centre for Development Innovation

Wageningen University \& Research

P.O. Box 88

6700 AB Wageningen

The Netherlands

$\mathrm{T}+31(0) 317486800$

www.wur.eu/cdi

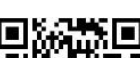

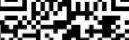

Fititis

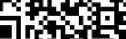

Wageningen Centre for Development Innovation supports value creation by strengthening capacities for sustainable development. As the international expertise and capacity building institute of Wageningen University \& Research we bring knowledge into action, with the aim to explore the potential of nature to improve the quality of life. With approximately 30 locations, 5,000 members of staff and 10,000 students, Wageningen University \& Research is a world leader in its domain. An integral way of working, and cooperation between the exact sciences and the technological and social disciplines are key to its approach. 